\title{
SENNETT, Richard. A corrosão do caráter - conseqüências pessoais do trabalho no novo capitalismo. Rio de Janeiro: Record, 2005.
}

Raphael Guilherme de Carvalho

Richard Sennett (1943 - ), nascido em Chicago, nos EUA, é sociólogo. Atualmente, vive e trabalha em Londres, Inglaterra, na "London School of Economics" e no MIT ("Massachussets Institut of Tecnology"). Sennett, como sociólogo, é um homem de preocupações "atuais". Seus trabalhos mais conhecidos versam sobre a sociedade contemporânea, sobre o "novo capitalismo", sobre a decadência da vida pública, sobre as cidades modernas - o urbano - e as relações, nelas, entre os indivíduos. É autor, entre outros, de "A cultura do novo capitalismo" (2006) e "O declínio do homem público" (1977).

A corrosão do caráter trata-se, conforme a definição do próprio autor, de um "ensaio-discussão", em que se mesclam elementos teóricos - sociológicos e filosóficos - e empíricos - as entrevistas e observações, muitas vezes informais, baseadas no exame da vida cotidiana, além dos dados estatísticos. A obra é dividida em oito capítulos, que discutem, em separado, mas não "isoladamente" (ou seja, sem perder de vista) os aspectos do novo capitalismo que concorrem para a "corrosão do caráter", ou o enfraquecimento de valores outrora fundamentais: o compromisso, a confiança, a lealdade. Entre estes aspectos, o mais fundamental para a compreensão do texto - e, claro, da realidade que nos toca diretamente em relação ao mundo do trabalho - é a noção de "capitalismo flexível".

Característica marcante do "novo capitalismo" - o de pelo menos duas décadas para cá -, a "flexibilidade" é sedutora e, por isso mesmo, enganosa. Ela insinua que se possa alcançar alguma liberdade individual, mas Sennett a desmistifica e afirma que a repulsão à rotina burocrática na verdade produz novas formas de poder e controle. $\mathrm{O}$ autor identifica os elementos que se escondem nas modernas formas 
de flexibilidade das empresas e produzem um sistema de poder: a reinvenção descontínua de instituições; a especialização flexível de produção; a concentração de poder sem centralização. Estas estratégias empresariais estão ligadas às necessidades financeiras de retorno imediato, de curtíssimo prazo, e às demandas, também instantâneas dos mercados consumidores. A aceleração dos prazos e processos, na ansiedade de obter resultados em curtíssimo prazo, permitiu aos funcionários um certo controle sobre suas próprias atividades - um "controle" na verdade vigiado, sobretudo por meio das contínuas inovações tecnológicas; estas, versões ainda mais sofisticadas das técnicas de vigilância.

A "organização do tempo" no novo capitalismo pode, segundo Sennett, nos mostrar como os três elementos se articulam. O "flexitempo", que se pretende um substituto "moderno" da burocracia rígida e racional - da qual trata Weber, um dos referenciais teóricos de Sennett -, intensifica a dominação e a alienação do trabalhador. Substitui-se, portanto, a rotina padronizada, monótona, por um mosaico de horários, de rotinas individualizadas. Na empresa, cada qual cumpre horários diferentes. Ela, a empresa, está funcionando, muitas vezes, sem parar. $\mathrm{O}$ trabalho em casa, supostamente "libertador", criou mecanismos eficientes para se controlar os ausentes do escritório: os trabalhadores deixam de encarar, face a face, o poder ao qual se submetem, mas estão submetidos às formas eletrônicas. Embora o trabalho fisicamente descentralizado, o poder sobre o trabalhador é, assim, mais direto.

O capitalismo dito flexível acaba por desviar os trabalhadores de um rumo único em suas carreiras. Talvez nem se possa pensar mais em "carreira" propriamente dita, uma vez que as pessoas fazem "partes de trabalho" durante suas vidas, se deslocam de uma cidade a outra com freqüência, mudam de trabalho assiduamente. Com isso, suas vidas deixam de produzir uma narrativa linear, são agora fragmentadas, aparecem como uma colagem incoerente; perde-se o vigor do seu sentido, perde-se até mesmo a autoria da própria vida. Esse descontínuo gera ansiedade, uma vez que se impõe a 
necessidade de constantemente correr riscos. Há assim forte impacto sobre o caráter pessoal nessa sociedade ansiosa, impaciente e imediatista.

A ética do trabalho também se altera: a seriedade da antiga ética do trabalho fazia as pessoas provarem seu valor pelo trabalho, para o que era necessária uma rigorosa disciplina e a automodelação em um único sentido, ou seja, uma carreira linear, conforme Weber. Hoje a "moderna" ética do trabalho prega a necessidade do trabalho em equipe, de constante adaptação e readaptação a pessoas e ambientes diferentes, por curtos períodos de tempo. Nela, mais uma ilusão: a de que os "chefes" não o são de fato, a de que não há antagonismo entre o chefe e o trabalhador. Nela, eles aparecem como "administradores" ou "guias" do grupo. Como demonstra Sennet, nada além de uma fuga de seu aspecto autoritário. Embora não haja mais a figura do chefe centralizador de poder, a dominação permanece permeando as relações de trabalho.

A lógica do trabalho em equipes produz o caráter do homem irônico, que não acredita em si mesmo pois sabe que depende de um contínuo recriar-se: nada é fixo, tudo está sujeito a mudanças repentinas, não há autoridade que reconheça os feitos deste homem irônico. A crescente informatização dos ambientes de trabalho, por sua vez,em substituição aos aparelhos mecânicos, não substitui apenas estes aparelhos, mas também a inteligência do trabalhador. Este último não cria laços de identidade com seu trabalho consequentemente, os laços de classe são frouxos. Conforme as entrevistas com os funcionários da padaria high-tech de Boston, o comprometimento com o trabalho é superficial, uma vez que se tornou ilegível para o trabalhador, que muitas vezes não entende o que faz.

Ouro aspecto interessante trabalhado por Sennett é o "fracasso", grande tabu moderno, que, ao invés de bater à porta dos desvalidos e desprivilegiados, é tema recorrente entre a classe média. Os entrevistados, ex-funcionários demitidos da IBM, concordam que o motivo de seus "fracassos" é exclusivamente por culpa individual. 
$\mathrm{Na}$ verdade, pouco refletem a respeito do colapso de suas carreiras, nem se empenham em construir narrativas sólidas sobre o que poderia reservar-lhes o futuro.

A indiferença é, portanto, outro fator de corrosão do caráter e seu corolário é a falta de confiança, aguçada pelo extremo individualismo. "Não há destino partilhado", disse Sennett. A frase final do livro é bastante instigante. Ela aponta uma crença? Um pessimismo? Uma alternativa? Uma provocação? Uma contradição do próprio "sistema"? Diz Sennet: "um regime que não oferece aos seres humanos motivos para ligarem uns para os outros não pode preservar sua legitimidade por muito tempo".

É importante ressaltarmos, neste momento, alguns apontamentos do autor a título de conclusão: o imediatismo e a ansiedade, a fragmentação e o flexitempo, o fosso entre as gerações, a indiferença e a alienação, todos estes fatores concorrem para uma amoralidade corruptora do caráter; o discurso da flexibilização, potencializado pelas novas tecnologias de comunicação, esconde, na verdade, novas ferramentas de controle, mascaradas por uma vaga e suspeita promessa de liberdade.

A corrosão do caráter traz à luz um valiosíssimo diagnóstico do tempo presente. Partindo, como se fora historiador, de problemas presentes, Sennett faz um estudo que nos permite visualizar com clareza as relações entre um presente imediato - o novo capitalismo e um passado não tão distante - o capitalismo de organização burocrática pensado por Weber - nos dois sentidos. Não podemos deixar de perceber, nem perder de vista, a preocupação política que permeia a obra. Sua preocupação com as cidades - estudioso que é do urbanismo - estão intimamente atreladas às preocupações políticas. Os destinos recentes das cidades apontam para a decadência da vida pública, para a superposição do social em relação ao político e para as privatizações (no sentido original, de privações).

É importante lembrarmos de Hannah Arendt e a valorização da pluralidade como condição básica da política e da existência dos homens em comunidade - o sentido da política é, desde sua origem 
histórica, na pólis arcaica e clássica, o espaço de prevalência da palavra, o diálogo. Lembramos de Deleuze e seu diagnóstico das sociedades de controle. Deleuze, como Sennett, desconfia das supostas "facilidades" e "confortos", como o acesso às contas bancárias de dentro de casa, via internet (o banco e seus mecanismos de vigilância e controle estão também dentro de casa). Lembramos também de Michel Foucault e o poder microfísico, ilegível ou não localizável.

A obra de Sennet, portanto, contribui de maneira bastante eficaz para o debate acerca da contemporaneidade, em diálogo com estes outros grandes pensadores comprometidos com o entendimento do presente vivido. Nela, o homem está presente, enquanto sujeito, ao mesmo tempo produtor e vítima de um sistema (ou regime) que, de acordo com Sennet, não se sustenta por muito tempo. Porque, de acordo com nossas conjecturas, não promove diálogo - nem política, em sua acepção original. 